\title{
Analysis Of Product Attributes And Brand Image Relationship To Consumer Buying Interest (Study At UD. Volkl Indonesia) In Surabaya
}

\author{
Budi Juliansyah dan Agus Baktiono \\ Program Studi Manajemen, Fakultas Ekonomi Dan Bisnis \\ Universitas Narotama Surabaya \\ Email author: agus.baktiono@narotama.ac.id
}

\begin{abstract}
UD. Volkl Indonesia is a sports equipment selling company that has a good target market for Indonesia .UD. This Volkl is on the HR road. Muhammad, Ruko Baverly Surabaya. UD. Volkl was founded for consumer demand from all over Indonesia as well as to expand the volkl brand tennis racket market. UD. Volkl in its production activities is more oriented towards providing sports equipment, especially racquets for the Indonesian market. Where the volkl company produces racket to support tennis athletes in the world, during the decade the volkl company has experienced fluctuations in sales up and down. However, volkl in its way expanded well and became the best in the national market. Therefore UD.Volkl Indonesia must think hard to achieve the output of its marketing program, purchase actions, and create loyal customers. Based on the tennis racket brand circulating in Indonesia, there are many kinds of products. The research objective was to determine the analysis of the relationship between product attributes and brand image on consumer buying interest (study at UD. Volkl in Hr. Muhammad). This type of research is quantitative. The population of this study were all athletes and registered consumers with a total sample size of 97 respondents who bought the Volkl brand tennis racket at UD. Volkl Indonesia at HR. Muhammad Surabaya. The sampling technique in this study was purposive sampling. The data collection technique in this study was carried out by distributing questionnaires. The data analysis technique used is the Pearson product moment correlation. The results of the conclusions obtained in this study show that the product attribute variable (X1) has a strong relationship with the consumer purchase interest variable (Y) and the brand image variable (X2) has a strong relationship with the consumer purchase interest variable (Y).
\end{abstract}

\section{Keyword:}

Product Attributes, Brand Image, Consumer Purchase Interest

\section{PENDAHULUAN}

\subsection{Latar Belakang}

Kemajuan teknologi membuat pembeli semakin cerdas untuk menentukan produk yang akan dibeli. Dalam kondisi seperti ini perusahaan harus mampu menterjemahkan factor-factor yang mempengaruhi pembeli untuk memilih produk sehingga perusahaan saling bersaing agar produknya terjual di pasaran. Dengan persaingan yang semakin ketat membuat perusahan saling menunjukkan keunggulannya masing- masing untuk menjadi pemimpin pasar. Oleh sebab itu, masing masing perusahaan selalu berfikir bagaimana usaha yang telah dijalaninya mampu berjalan sesuai dengan apa yang telah diharapkan

Tenis lapangan merupakan salah satu jenis cabang olah raga yang menggabungkan unsur ketahanan dan kelenturan fisik. Olahraga ini lahir sejak zaman yunani, mesir dan romawi . Pada awalnya, tenis lapangan dimainkan dengan menggunakan raket dan bola. Perkembangan tenis di Indonesia semakin pesat terlihat dari keikutsertaan tiga wakil pribumi pada semacam kejuaraan nasional yang diadakan oleh beberapa institusi, salah satunya adalah De Alegemeene di Malang, Jawa Timur. Pada akhir tahun 1934 mereka telah mampu mengalamai masa kejayaan di partai tunggal putra, dua saudara Soemadi dan Samboedjo Hoerip, mereka maju dibabak final. Dari sejarah prestasi ini mendorong para petenis muda mengadakan Pekan Olahraga Nasional (PON) yang diselenggarakan secara berkala tiap tahunnya. Kota Surabaya adalah salah satu kota di Indonesia yang pernah menjadi tuan rumah pada pelaksanaan PON tersebut.

Olah raga Tenis Lapangan semakin berkembang ketika atribut penunjang olah raga tenis yang dinamakan raket menjadi suatu barang yang penting dan harus dimiliki jika ingin bermain tenis lapangan . Di Indonesia, tenis lapangan adalah olahraga populer karena pundi-pundi prestasi di masa yang lalu menjadi catatan sejarah yang membanggakan. Yayuk Basuki adalah salah satu atlet tenis lapangan profesional yang pernah menjuarai berbagai turnamen tenis bertaraf internasional, ia pernah memperkuat tim Indonesia di ajang Davis Cup pada tahun 1998, bahkan Indonesia menjadi juara saat itu. 
Dalam permainan tennis, raket merupakan peralatan fital yang sangat dibutuhkan. Sehingga, perkembangan industry raket semakin berkembang seiring dengan perkembangan peminat olah raga tersebut tenis. Jenis raket yang beredar di pasaran sangat beragam mulai dari kualitas bahan sampai merk.

Persaingan pasar raket tenis lapangan di Indonesia menjadi semakin ketat di masa kini. Sebagai brand baru, Volkl sudah berdiri sejak 10 tahun di Indonesia, volkl harus berfikir keras guna mencapai output dari program pemasarannya, tindakan pembelian serta menciptakan konsumen yang loyal. Berdasarkan brand raket tenis lapangan yang beredar di Indonesia banyak macam - macam produk seperti, Wilson, Babolat, Dunlop, Yonex, Technifiber, Head. Semakin banyaknya brand yang beredar di pasar, akan membuat semakin banyak masyarakat penggemar olahraga tenis lapangan dihadapkan pada alternative pilihan merk raket yang sesuai dengan yang diinginkannya.

UD. Volkl Indonesia membutuhkan kegiatan pemasaran yang baik. Dengan kegiatan pemasaran yang baik, maka perusahaan akan mampu merencanakan strategi pemasaran yang tepat dan sesuai yaitu strategi pemasaran yang dapat mencitptakan posisi yang kuat dalam menghadapi persaingan. Strategi pemasaran yang tepat dan sesuai merupakan strategi yang dapat menye-imbangkan dan menyelaraskan anatara apa yang dimiliki oleh perusahaan dengan apa yang berasal dari luar perusahaan atau biasa di sebut lingkungan perusahaan.

Lingkungan perusahaan dibagi kedalam dua kategori yaitu lingkungan internal dan lingkuangan eksternal. Lingkungan internal menggambarkan kekuatan dan kelemahan yang dimiliki oleh UD. Volkl Indonesia. Dengan mengeathui kekuatan dan kelemahanya, UD. Volkl Indonesoia akan dapat memaksimalkan kekuatan dan meminimalkan kelemahan yang ada. Sedangkan lingkungan eksternal menggambarkan peluang dan ancaman yang yang akan dihadapi oleh UD. Volkl Indonesia., dimana perusahaan dapat memanfaatkan peluang yang ada dan menghindari ancaman yang datang pada perusahaan.

Fenomena persaingan brand raket tenis sangat ketat di Indonesia, sebagai brand raket tenis lapangan yang tergolong baru di Indonesia, volkl harus bersaing dengan kompetitor - kompotitor terdahulunya dan harus bisa menjadikan volkl sebagai brand produk yang mudah di ingat konsumen. Wilson misalnya produk asal China ini sudah sangat di kenal oleh banyak orang sebagai produk yang paling banyak di minati para atlet- atlet nasional maupun internasional, itu dibuktikan pada setiap pertandingan yang ada di Indonesia banyak yang menggunakan raket merek Wilson dibandingkan merek lain.

Tabel 1 Analisis Persaingan Produk Raket Tenis Lapangan

\begin{tabular}{|c|c|c|c|c|}
\hline Merk & Kualitas & Harga & Bahan & Target Segmen \\
\hline Volkl & cukup & $\begin{array}{c}\text { Rp 1.000.000- } \\
2.500 .00\end{array}$ & Bagus & $\begin{array}{l}\text { Atlet dan } \\
\text { penggemar } \\
\text { tennis }\end{array}$ \\
\hline Wilson & Sangat baik & $\begin{array}{c}\text { Rp . } 2.000 .000- \\
3.000 .000\end{array}$ & Sangat bagus & $\begin{array}{l}\text { Atlet dan } \\
\text { penggemar } \\
\text { tennis }\end{array}$ \\
\hline Babolat & Baik & $\begin{array}{c}\text { Rp. } 1.700 .000- \\
2.200 .000\end{array}$ & Bagus & $\begin{array}{l}\text { Atlet dan } \\
\text { penggemar } \\
\text { tennis }\end{array}$ \\
\hline Dunlop & Baik & $\begin{array}{c}\text { Rp. } 1.900 .000- \\
2.250 .000\end{array}$ & Bagus & $\begin{array}{l}\text { Atlet dan } \\
\text { penggemar } \\
\text { tennis }\end{array}$ \\
\hline Yonex & Baik & $\begin{array}{c}\text { Rp. } 2.000 .000 .- \\
2.300 .000\end{array}$ & Bagus & $\begin{array}{l}\text { Atlet dan } \\
\text { penggemar } \\
\text { tennis }\end{array}$ \\
\hline Technifiber & Baik & $\begin{array}{c}\text { Rp. } 1.700 .000- \\
2.000 .000\end{array}$ & Bagus & $\begin{array}{l}\text { Atlet dan } \\
\text { penggemar } \\
\text { tennis }\end{array}$ \\
\hline Head & Sangat baik & $\begin{array}{c}\text { Rp. } 2.000 .000- \\
2.700 .000\end{array}$ & Sangat bagus & $\begin{array}{l}\text { Atlet dan } \\
\text { penggemar } \\
\text { tennis }\end{array}$ \\
\hline
\end{tabular}

Sumber : Hasil survey lapangan penulis.

Berdasarkan ilustrasi data pada table 1.1 diatas, dapatlah penulis jelaskan bahwa produk raket tenis lapangan merk Volkl memiliki kualitas yang cukup, dibandingkan dengan merk-merk yang selama ini beredar di pasaran. Di Indonesia yang sekarang ini memimpin pasar raket tennis yang banyak diminati para atlete-atlet nasional di Indonesia adalah Wilson dan Head.

Dalam memilih produk, konsumen tentu saja akan dipengaruhi oleh atributdari produk. Atribut produk merupakan segala sesuatu yang melekat dan menyertai produk tersebut, seperti merk, desain, warna, kualitas dan sebagainya. Atribut produk merupakan salah satu unsur penting yang dapat mendorong konsumen untuk 
membeli produk, semakin baik atribut produk maka konsumen akan semakin tertarik untuk membeli produk tersebut.

Atribut produk adalah pengembangan produk atau jasa yang melibatkan penentuan manfaat yang akan diberikan. (Kotler 2008). Berdasarkan pengertian atribut produk tersebut maka dapatlah dikatakan bahwa atribut produk raket tenis merk Vokl, dimata konsumen pada umumnya memiliki variasi dan kualitas yang baik sehingga konsumen dapat memilih raket mana yang disukai.

Brand image (citra merk) merupakan representasi dari keseluruhan persepsi terhadap merek dan dibentuk dari informasi dan pengalaman masa lalu terhadap merek itu. Berdasarkan pengertian citra merk diatas, merk raket tenis Vokl dikalangan pengguna raket renis pada umumnya memiliki kualitas yang baik dan mempunyai technologi canggih.

Tabel 2 Perkembangan Penjualan Raket Tenis Lapangan Merk Volk

\begin{tabular}{ccc}
\hline Periode & $\begin{array}{c}\text { Target Penjualan } \\
\text { (unit) }\end{array}$ & $\begin{array}{c}\text { Realisasi Penjualan } \\
\text { (unit) }\end{array}$ \\
\hline 2011 & 1000 & 1080 \\
2012 & 1100 & 800 \\
2013 & 1100 & 900 \\
2014 & 1100 & 1200 \\
2015 & 1300 & 1310 \\
\hline
\end{tabular}

Sumber : PT. Volkl Indonesia

Berdasarkan ilustrasi pada table 1.2 diatas, maka dapatlah penulis berikan penjelasan bahwa volume penjualan raket tenis merk Volkl selama kurun waktu periode tahun 2011 - 2015 mengalami fluktuasi penjualan yang naik turun. Pada periode tahun 2011-2013 penjualan raket volkl mengalami penurunan yang sangat besar. Hal ini di sebabkan karena adanya perubahan kebijakan dari manajemnen volkl internasional yang bermarkas di jerman, mereka merubah merek Volkl menjadi merek Boris Becker. Perubahan ini dikarenakan saham volkl 90\% telah diambil alih oleh Boris becker.

Penurunan penjualan merek Boris becker di Indonesia disebabkan karena banyak konsumen yang belum tahu dengan baru tersebut, disamping itu pada era tahun 90an di Indonesia pernah beredar merek Boris becker dengan kualitas yang kurang bagus. Merek boris becker ini bukan produk yang original tapi merupakan produk palsu. Akibat image yang jelek ini membuat para konsumen ragu dengan merek boris beclker yang baru. Mereka masih berasumsi bahwa merek Boris becker yang ada saat ini tidak jauh beda dengan merek Boris becker yang ada pada era tahun 90an.

Melihat kondisi penjualan merek boris becker yang mengalami penurunan baik di Indonesia maupun di tingkat internasional, maka manajemen vokl mengambil tindakan kebijakan dengan merubah kembali dari merek boris becker menjadi merek volkl. Dengan perubahan ini secara perlahan penjualan volkl kembali meningkat, hal ini bisa dilihat dari penjualan vokl pada tahun 2014-2015.

Minat pembelian adalah sesuatu yang diperoleh dari proses belajar dan proses pemikiran yang membentuk suatu persepsi. Minat beli ini menciptakan suatu motivasi yang terus terekam dalam benaknya dan menjadi suatu keinginan yang sangat kuat dan pada akhirnya ketika seorang konsumen harus memenuhi kebutuhannya akan mengaktualisasikan apa yang ada didalam benaknya itu ( Mowen, Oliver (2006). Sesuai dengan pengertian diatas, minat pembelian masyarakat yang gemar olahraga tenis dalam membeli raket tenis sangat beragam. Oleh karena itu masyarakat masih bingung untuk memilih raket mana yang ingin digunakan untuk bermain tenis. Hal ini menjadi tantangan bagi perusahaan dalam membaca minat atau selera konsumen, perusahaan harus mampu menterjemahkan factor apa saja yang mempengaruhi minat pembelian.

Berdasarkan uraian pada latar belakang masalah diatas, maka penulis kemudian tertarik untuk mengangkat fenomena dan topic ini sehingga menjadi judul penelitian " Analisis Hubungan Atribut produk dan Brand Image Terhadap Minat Beli Konsumen ( study pada UD. Volkl di HR. Muhammad Surabaya) ".

\subsection{Rumusan Masalah}

Berdasarkan fenomena pada latar belakang penelitian tersebut diatas, maka permasalahan yang penulis coba angkat dalam penelitian ini adalah : apakah atribut produk dan brand image mempunyai hubungan terhadap minat beli konsumen ( study pada PT.VOLKL di Hr. Muhammad ) ?

\section{Tinjauan Pustaka}

Nandia Agy Nilawati dalam penelitiannya (2012 ) "Pengaruh Atribut Dan Referensi Komunitas Terhadap Minat Beli Ulang Pada Kafe Kopi Miring Di Semarang . Penelitian ini dilatarbelakangi oleh semakin berkembangnya bisnis usaha penyajian makanan terutama dalam bentuk kafe di Kota Semarang yang 
mempengaruhi keputusan membeli yang menjadi minat beli ulang konsumen. Minat beli ulang yang tinggi menunjukkan tingkat kepuasan konsumen dalam melakukan pembelian dan konsumsi. Berdasarkan data penjualan pada tahun 2011 hingga awal 2012 menunjukka bahwa kopi miring mengalami penjualan fluktuatif. Oleh karena itu, ditemukan dua variable yang mempengaruhi minat beli ulang konsumen yaitu atribut produk dan referensi komunitas yang digunakan dalam penelitian ini. Tujuan penelitian adalah untuk mengetahui apakah atribut dan referensi komunitas berpengaruh terhadap minat beli ulang konsumen Kopi Miring. Populasi yang digunakan dalam penelitian ini adalah konsumen Kopi Miring yang melakukan pembelian tiga kali atau lebih. Sampel pada penelitian ini sebanyak 96 responden dengan menggunakan metode simple random sampling yang kebetulan berada di Kopi Miring. Analisis terhadap data yang diperoleh berupa analisis kuantitatif dan kualitatif. Hasil penelitian ini menunjukkan bahwa semua variable independen secara bersama - sama berpengaruh secara posotif terhadap minat beli ulang dan berpengaruh positif secara individual terhadap minat beli ulang. Dengan demikian, atribut produk dan referensi komunitas memiliki pengaruh positif dan signifikan terhadap minat beli ulang konsumen di Kopi Miring Semarang dimana variable menunjukkan adanya pengaruh nilai sebessar $42,5 \%$.

\subsection{Pengertian pemasaran}

Menurut Philip kotler (2005: 9), Pemasaran adalah suatu proses social yang didalamnya individu dan kelompok mendapatkan apa yang mereka butuhkan dan inginkan dengan menciptakan, menawarkan dan secara bebas mempertukarkan produk yang benilai dengan pihak lain. Pemasaran seiring digambarkan sebagai " seni menjual produk". Tujuan pemasaran adalah untuk mengetahui dan memahami pelanggan sedemikian rupa sehingga produk atau jasa itu dapat sesuai dengan kebutuhan pelanggan.

Menurut William J. Stanton (2007: 113), Pemasaran adalah suatu sistem keseluruhan dari kegiatan kegiatan bisnis yang ditujukan untuk merencanakan, menentukan harga, mempromosikan, dan mendistribusikan barang dan jasa yang memuaskan kebutuhan, baik kepada pembeli yang ada maupun pembeli potensial

Berdasarkan beberapa definisi mengenai konsep pemasaran diatas, dapat disimpulkan bahwa pemasaran merupakan usaha terpadu dalam penggabungan rencana - rencana strategis mengenai upaya pemuas kebutuhan dan keinginan pelanggan. Kegiatan pemasaran perusahan harus dapat memberikan kepuasan kepada pelanggan untuk mendapatkan respon yang positif. Segala kegiatan dan aktifitas perusahaan yang optimal sebagai produsen berfokus untuk memuaskan kebutuhan pelanggan dengan tujuan akhir memperoleh profit.

\subsection{Konsep Pemasaran}

Konsep pemasaran menurut Kotler dan Keller. ( Dr.Ir.H. nanda limakrisna.,MM.,CQM dan Dr.Ir.Wilhelmus hary susilo., MM., IAI . halaman 27 penerbit mitra wacana media) terdiri dari :

1. Konsep produksi, mungkin filosofi tertua, mengatakan bahwa konsumen akan lebih memilih produk yang tersedia seacara luas dan murah. Oleh karena itu focus organisasi harus mengusahakan biaya rendah dan mudah mengaksesnya. Contoh: pompa bensin milik swasta (shell atau petronas) dan pengumpul sampah di sector publik.

2. Konsep produk, mengatakan bahwa konsumen akan lebih menyenangi produk yang menawarkan mutu, penampilan/kinerja atau fitur inovatif terbaik. Masalah yang timbul adalah bahwa manajer program dan jasa sering mengabaikan kebutuhan dan keinginan pelanggan. Semboyan yang di pergunakan " built it and they will come" atau "make it and it will sell " supply create it's own demand".

3. Konsep penjualan, mengatakan bahwa konsomen dan bisnis mungkin tidak akan membeli secara cukup produk dari organisasi untuk memenuhi tujuan kalau dibiarkan tanpa dipengaruhi. Akibatnya organisasi harus berusaha menjual dan mempromosikan secara agresif.

4. Konsep pemasaran, tujuan pemasaran ialah mengetahui dan memahami pelanggan pelanggan dan jasa cocok/sesuai dengan yang dikehendaki pelanggan dan terjual dengan sendirinya.

5. Konsep pemasaran social, konsep ini mengatakan bahwa organisasi harus mengembangkan dan menyampaikan nilai superior kepadan pelanggan yang sedikit banyak mempertahankan atau memperbaiki kesejahteraan pelanggan dan masyarakat luas. Konsep pemasaran social mempersilahkan pemasaran membangun/ membentuk pertimbangan social dan etika kedalam praktek pemasaran.

\subsection{Bauran Pemasaran}

Pemasaran mefasilitasi proses pertukaran dan pengembangan hubungan dengan konsumen dengan cara mengamati secara cermat kebutuhan dan keinginan konsumen yang di lanjutkan dengan mengembangkan suatu produk (product) yang memuaskan kebutuhan konsumen dan menawarkan produk tersebut pada harga (price) tertentu serta mendistribusikannya agar tersedia di tempat-tempat (place) yang menjadi pasar bagi produk bersangkutan. Untuk itu perlu dilaksanakan suatu promosi (promotion) atau komunikasi guna menciptakan kesadaran dan ketertarikan kepada bersangkutan. Proses ini disebut dengan marketing mix atau bauran pemasaran yang terdiri atas elemen-elemen yaitu : product, price, place, dan promotion yang biasa disingkat dengan 4 (empat) P. 


\subsection{Pengertian Perilaku Konsumen}

Menurut Engel, Blackwell, dan Miniard (1995), mendefinisikan perilaku konseumen sebagai tindakan yang langsung terlibat dalam mendapatkan, mengonsumsi, produk dan jasa, termasuk proses keputusan yang mendahului dan menyusuli tindakan ini.

Menurut winardi (1991), perilaku konsumen dapat dirumuskan sebagai perilaku yang di tunjukan oleh orang orang dalam hal merencanakan barang barang ekonomi dan jasa jasa. Sedangkan perilaku pembeli (buyer behavior) musatkan perhatian pada perilaku individu khusus, yang membeli produk yang bersangkutan, sekalipun orang itu tidak terlibat dalam hal merencanakan pembelian tersebut, atau menggunakan produk tersebut.

Gerald Zaltman dan Melanie Walendorf, menjelaskan bahwa “ consumer behavior are acts, processes ang social relation ship exhibite by individuals, group and organization in the obtaiment, use of, and consequent experience with product, service and other resources “. ( perilaku konsumen adalah tindakan - tindakan , proses, dan hubungan social yang dilakukan oleh individu, kelompok, dan organisasi dalam mendapatkan, menggunakan suatu produk atau lainnya sebagai suatu akibat dari pengalamannya dengan produk, pelayanan, dan sumber - sumber lainnya).

Berdasarkan 3 pengertian diatas, penulis dapat mengambil kesimpulan bahwa perilaku konsumen adalah tindakan - tindakan yang di lakukan oleh individu, kelompok, atau organisasi yang berhubungan dengan proses pengambilan keputusan dalam mendapatkan, menggunakan barang - barang dan jasa ekonomis yand dapat dipengaruhi oleh lingkungan.

\section{Metode Penelitian}

Penelitian ini merupakan jenis penelitian kuantitatif yang dilakukan dengan menggunakan pendekatan deskriptif. Penelitian ini bertujuan untuk mengetahui adanya hubungan atribut produk dan citra merk (brand image) terhadap Minat Pembelian konsumen dalam membeli produk raket tenis lapangan merk Volkl. Menurut Winarsunu (2002:11) populasi adalah kelompok subjek atau objek yang memiliki ciri-ciri atau karakteristikkarakteristik tertentu yang berbeda dengan kelompok subjek atau objek yang lain, dan kelompok tersebut akan dikenai generalisasi dari hasil penelitian. Pada penelitian ini populasinya adalah seluruh konsumen yang membeli produk raket tenis lapangan merk Volkl pada UD. Volkl Indonesia di HR. Muhammad Surabaya. Untuk keperluan pengambilan data pada penelitian ini, maka akan diambil sebagian dari populasi tersebut dan selanjutnya disebut sebagai sampel. Sampel yang baik adalah sampel yang anggota-anggotanya mencerminkan sifat-sifat dan ciri-ciri yang terdapat pada populasi (Winarsunu, 2002: 11). Oleh karena itu sampel yang diambil dari populasi harus benar-benar representatif.

Teknik sampel dalam penelitian ini adalah purposive sampling. Dalam purposive sampling pemilihan sekelompok subyek didasarkan atas ciri-ciri atau sifat-sifat tertentu yang dipandang mempunyai sangkut paut yang erat dengan ciri-ciri atau sifat-sifat populasi yang sudah diketahui sebelumnya (Hadi, 2004:186), yaitu :

1. Konsumen yang dipilih atlet dan hanya yang melakukan pembelian di UD. Volkl Indonesia di HR. Muhammad Surabaya.

2. Konsumen yang dipilih hanya yang melakukan pembelian raket tenis lapangan merk Volkl di PT. Volkl Indonesia di HR. Muhammad Surabaya.

Pertanyaan - pertanyaan dalam kuesioner tersebut disertai jawaban dengan menggunakan skala likert 1-5 untuk mendapatkan data yang bersifat interval, dimana dengan menggunakan skala 1-5, adalah merupakan bentuk kebiasaan orang dalam memberikan penilain. Jawaban-jawaban yang tersedia pada skala tersebut diberi skor atau nilai sebagai berikut :

1. Sangat Tidak Setuju (STS) skor atau nilai (1)

2. Tidak Setuju (TS) skor atau nilai (2)

3. Cukup Setuju (CS) skor atau nilai (3)

4. Setuju (S) skor atau nilai (4)

5. Sangat Setuju (SS) skor atau nilai (5)

Diketehui bahwa jumlah responden sebanyak 97 adalah jenis kelamin pria sebanyak 65 dengan presentase $65 \%$, sedangkan responden wanita sebanyak 32 dengan presentase $32 \%$. Responden dengan usia 1720 tahun sebanyak 7 dengan presentase 7\% , 20-25 tahun sebanyak 19 dengan presentase 19\%, 25-30 tahun sebanyak 59 dengan presentase 59\%, >30 tahun sebanyak 12 dengan presentase $12 \%$. Responden berdasarkan status belum kawin sebanyak 49 dengan presentase 49\%, kawin sebanyak 48 dengan presetase $48 \%$. Responden berdasarkan status, <SLTA/sederajat sebanyak 46 dengan presentase $46 \%$, sarjana sebanyak 42 dengan presentase $42 \%$, pascasarjana sebanyak 9 dengan presentase $9 \%$. 


\subsection{Pengukuran}

Menurut Husein $(2002 ; 101)$, yang dimaksud dengan validitas adalah pernyataan sampai sejauh mana data yang ditampung pada suatu kuisioner dapat mengukur apa yang ingin diukur.

Tabel 3 Pengukuran

\begin{tabular}{ccccc}
\hline Variabel & Item & $\begin{array}{c}\text { Koefisien } \\
\text { korelasi ( } \mathrm{r}_{\text {hitung) }}\end{array}$ & $\mathrm{r}_{\text {table }}$ & Keterangan \\
\hline $\mathrm{X} 1$ & $\mathrm{X} 1.1$ & 0,318 & 0,1996 & Valid \\
& $\mathrm{X} 1.2$ & 0,479 & 0,1996 & Valid \\
& $\mathrm{X} 1.3$ & 0,511 & 0,1996 & Valid \\
& $\mathrm{X} 1.4$ & 0,424 & 0,1996 & Valid \\
& $\mathrm{X} 1.5$ & 0,505 & 0,1996 & Valid \\
& $\mathrm{X} 1.6$ & 0,513 & 0,1996 & Valid \\
& $\mathrm{X} 1.7$ & 0,615 & 0,1996 & Valid \\
& $\mathrm{X} 1.8$ & 0,505 & 0,1996 & Valid \\
$\mathrm{X} 2$ & $\mathrm{X} 1.9$ & 0,236 & 0,1996 & Valid \\
& $\mathrm{X} 2.1$ & 0,616 & 0,1996 & Valid \\
& $\mathrm{X} 2.2$ & 0,497 & 0,1996 & Valid \\
& $\mathrm{X} 2.3$ & 0,792 & 0,1996 & Valid \\
$\mathrm{Y}$ & $\mathrm{Y} .1$ & 0,652 & 0,1996 & Valid \\
& $\mathrm{Y} .2$ & 0,506 & 0,1996 & Valid \\
& $\mathrm{Y} .3$ & 0,614 & 0,1996 & Valid \\
& $\mathrm{Y} .4$ & 0,229 & 0,1996 & Valid \\
& $\mathrm{Y} .5$ & 0,483 & 0,1996 & Valid \\
\hline
\end{tabular}

Pada tabel diatas dapat diketahui bahwa pertanyaan-pertanyaan dalam kuesioner tersebut dinyatakan valid karena nilai korelasinya dari tiap item pertanyaan lebih besar dari nilai kritisnya atau rhitung > rtabel. Dengan demikian kuisioner yang diajukan kepada responden dapat dinyatakan valid, berarti kuesioner itu mampu mengukur apa yang hendak diukur dan mampu mengungkap apa yang hendak di ungkap dalam penelitian.

Tabel 4 Pengukuran

\begin{tabular}{ccccc}
\hline Variabel & Item & $\begin{array}{c}\text { Cronbach's Alpha if Item } \\
\text { Deleted }\end{array}$ & $\mathrm{r}_{\text {table }}$ & Keterangan \\
\hline X1 & X1.1 & 0,868 & 0,6 & Reliabel \\
& X1.2 & 0,860 & 0,6 & Reliabel \\
& X1.3 & 0,859 & 0,6 & Reliabel \\
& X1.4 & 0,863 & 0,6 & Reliabel \\
& X1.5 & 0,859 & 0,6 & Reliabel \\
& X1.6 & 0,859 & 0,6 & Reliabel \\
& X1.7 & 0,854 & 0,6 & Reliabel \\
& X1.8 & 0,859 & 0,6 & Reliabel \\
& X1.9 & 0,872 & 0,6 & Reliabel \\
X2 & X2.1 & 0,855 & 0,6 & Reliabel \\
& X2.2 & 0,860 & 0,6 & Reliabel \\
& X2.3 & 0,848 & 0,6 & Reliabel \\
& Y .1 & 0,854 & 0,6 & Reliabel \\
& Y .2 & 0,859 & 0,6 & Reliabel \\
& Y.3 & 0,854 & 0,6 & Reliabel \\
& Y.4 & 0,871 & 0,6 & Reliabel \\
& Y.5 & 0,860 & 0,6 & Reliabel \\
\hline
\end{tabular}

Sumber : Hasil analisis SPSS, diolah penulis. 2016

Bisa dilihat bahwa di tabel tersebut, data penelitian ini mempunyai cronbach alpha .870 dan berada di atas 0.60 , maka data penelitian ini dapat dinyatakan reliabel dan dapat dipercaya. 


\section{Hasil dan Pembahasan}

Menurut (Sujiweni. 2014) uji korelasi pearson bertujuan untuk menguji hubungan antara dua variable yang berisi data kuantitatif yaitu data angka yang sesunguhnya yang didapat dari jawaban para responden. Untuk mengetahui signifikanya sebuah data dapat dilihat dari nilai $\mathbf{r}$, untuk melihat hubungan antara variable kualitas produk, harga, kualitas layanan terhadap kepuasan pelanggan mengunakan uji korelasi pearson sebagai berikut.

\begin{tabular}{|c|c|c|c|c|}
\hline \multicolumn{5}{|c|}{ Tabel 5 Korelasi } \\
\hline & & $\mathrm{x} 1$ & $\mathrm{x} 2$ & $\mathrm{Y}$ \\
\hline \multirow[t]{3}{*}{$\mathrm{x} 1$} & Pearson Correlation & 1 & $.695^{* *}$ & $.735^{* *}$ \\
\hline & Sig. (2-tailed) & & .000 & .000 \\
\hline & $\mathrm{N}$ & 97 & 97 & 97 \\
\hline \multirow[t]{3}{*}{$\mathrm{x} 2$} & Pearson Correlation & $.695^{* *}$ & 1 & $.694^{* *}$ \\
\hline & Sig. (2-tailed) & .000 & & .000 \\
\hline & $\mathrm{N}$ & 97 & 97 & 97 \\
\hline \multirow[t]{3}{*}{ Y } & Pearson Correlation & $.735^{* * *}$ & $.694^{* *}$ & 1 \\
\hline & Sig. (2-tailed) & .000 & .000 & \\
\hline & $\mathrm{N}$ & 97 & 97 & 97 \\
\hline
\end{tabular}

Nilai korelasi menurut (sugiyono. 2002) adalah sebagai berikut :

\begin{tabular}{cc}
\multicolumn{2}{c}{ Tabel 6 Nilai Korelasi } \\
\hline Inter kvaloefisien & Tingkatan hubungan \\
\hline $0,00-0,199$ & Sangat rendah \\
$0,200-0,399$ & Rendah \\
$0,400-0,599$ & Sedang \\
$0,600-0,799$ & Kuat \\
$0,800-1,000$ & Sangat kuat \\
\hline
\end{tabular}

Sumber : Sugiyono, 2005

Keputusan :

Jika sig $>0,05$ maka Ho diterima

Jika sig $<0,05$ maka Ho ditolak

Dari hasil korelasi diatas maka dapat di tunjukan hasilnya sebagi berikut :

1. Uji korelasi pearson antara variabel atribut produk (X1) dengan variable minat beli (Y) berdasarkan penghitungan SPSS diatas maka diperoleh diperoleh korelasi sebesar 0.735. Hal ini berarti bahwa variabel atribut produk (X1) memiliki hubungan yang kuat dengan variabel Minat beli konsumen. Dan variable atribut produk memiliki signifikan level sebesar $0.000<$ dari 0.05 . Dengan demikian variabel atribut produk (X1) memiliki hubungan yang kuat dan signifikan dengan variabel minat beli konsumen, sehingga Ho ditolak dan Ha diterima.

2. Uji korelasi pearson antara varibel brand image (X2) dengan varibel minat beli (Y). berdasarkan penghitungan SPSS diatas maka diperoleh diperoleh korelasi sebesar 0,694. Hal ini berarati bahwa variabel brand image (X2) memiliki hubungan yang kuat dengan variabel minat beli konsumen. Dan variable brand image memiliki signifikan level sebesar $0,000<$ dari 0,05 . Dengan demikian variabel brand image (X2) memiliki hubungan yang kuat dan signifikan dengan variabel minat beli konsumen, sehingga Ho ditolak dan Ha diterima.

\section{Penutup}

\subsection{Kesimpulan}

1. Perhitungan dengan SPSS 18 menunjukan nilai koefisien produk moment variable atribut produk (X1) mepunyai hubungan yang kuat terhadap minat beli (Y) dan signifikan. hal titu bisa dilihat dari hasil olahan data SPPS yang sudah di jelaskan sebelumnya. Dimana Ho ditolak karena nilai sig kurang dari 0,05 yaitu sebsar 0.000 dan Ha diterima. 
2. Variable brand image (X2) mepunyai hubungan yang kuat terhadap minat beli (Y) dan signifikan. hal itu bisa dilihat dari hasil olahan data SPPS yang sudah di jelaskan sebelumnya. Dimana Ho ditolak karena nilai sig kurang dari 0,05 yaitu sebsar 0.000 dan Ha diterima.

\section{Daftar Pustaka}

Aaker, D. A. 2001 Strategic Market Management. USA : John Wiley \& Sons, INC.

Aaker, David. 1991. Managing Brand Equity: Capitalizing on the value of Name. New York: The Free Press.

Anoraga, Pandji. 2000. Manajemen Bisnis.Jakarta: Penerbit PT. Rineka Cipta

Badan Pusat Statistik. 2011. Data Strategis BPS. Jakarta: Badan Pusat Statistik

Boyd, Harper W., Orville C. Walker, Jean Claude Larreche. 2000. Manajemen Pemasaran.Suatu Pendekatan Strategis dengan Orientasi Global. Jilid satu. Edisi kedua. Alih Bahasa:Imam Nurmawan. Jakarta:Erlangga.

Cliffs, New Jersey, International Edition

Engel, James dkk. 1993. Perilaku konsumen Edisi keenam. Jilid dua. Edisi bahasa Indonesia. Jakarta: Binarupa Alfabeta.

Ghozali, I 2005. Multivariate dengan program SPSS Semarang : Badan Penerbit Universitas Diponegoro.

Hermawan Kertajaya, 2002, Marketing in Venus, Jakarta : Gramedia Pustaka Utama

Keller, Kevin Lane. 2003. Strategic Brand Management, Building, Measuring, and managing Brand Equity. New Jersey: Prentice Hall.

Kolopita, D. A., \& Soegoto, A. S. (2015). Analisis Atribut Produk Dan Harga Terhadap Minat Beli Mobil Suzuki Ertiga Di Kota Manado. Jurnal EMBA Vol.3 No.2 Juni ISSN 2303-1174, 12-24.

Kotler, Philip dan Kevin Lane Keller. 2011. Manajemen Pemasaran Edisi 13, Jilid 1, Terjemahan. Jakarta: PT. Indeks.

Mowen, John C, 2001, “Consumers Behavior”, Prentice Hall, Inc, Englewood

Parasuraman, A, Valarie, A, Zeithaml, \& L, Berry, (1985), "Communication and Control Processes in the Delivery of Service Quality” Journal of Marketing, Vol, 52,pp,35-48,

Parasuraman. A, Zeithalm.V.A, Malhotra A, 2000, "ESQUAL A multiple Item Scale for Accessing Service Quality”. Journal of Service Research Vol 7

Pradipta, H. O. (2015). Pengaruh Citra Merek, Periklanan Terhadap MInat Beli Konsumen Thermometer Onemed Di Surabaya. Jurnal Ilmu dan Riset Manajemen Volume 4, Nomor 7, Juli.

Rizky, M. F., \& Yasin, H. (2014). Pengaruh promosi dan harga terhadap minat beli perumahan obama PT. Nailah Adi Kurnia SEI Mencirim Medan. Jurnal Manajemen \& Bisnis Vol 14 No. 02 Oktober 2014 ISSN 1693-7619.

Schiffman, Leon dan Leslie Lazar Kanuk. 2008. Perilaku Konsumen. Edisi ketujuh. Cetakan keempat. Jakarta:PT Indeks.

Simamora, Bilson. 2003. Memenangkan Pasar dengan Pemasaran Efektif dan Profitabel. Cetakan kedua. Jakarta:PT Gramedia Pustaka Utama.

Singarimbun, Masri. 2006. Metode Penelitian Survai. Edisi revisi. Jakarta:LP3ES.

Stanton, William J.,Michael J. Etzel, dan Bruce J. Walker. 1991. Fundamentals of Marketing. Edisi kesembilan. McGraw-Hill.

Sulistyari, I. N., \& Yoestini. (2012). Analisis Pengaruh Citra Merek, Kualitas Produk, Dan Harga Terhadap Minat Beli Produk Oriflame (Studi Kasus Mahasiswi Fakultas Ekonomika dan Bisnis Jurusan Manajemen Universitas Diponegoro Semarang). Diponegoro Journal Of Management Volume 1, Nomor 1, 1-17.

Sumarwan, Ujang. 2011. Perilaku Konsumen Teori dan Penerapannya Dalam Pemasaran. Bogor: Ghalia Indonesia.

Tjiptono, Fandy. 2005. Pemasaran Jasa. Malang : Banyumedia Publishing

Yaqian Zhou. 2011. The Impact of Customer-Based Brand Equity on Revisit Intentions: An Empirical Study of Business and Leisure Travelers at Five Shanghai Budget Hotels. AU-GSB eJournal (Online) Vol. 4, No. 1 pp. 168-181 (http://gsbejournal.au.edu diakses pada tanggal 1 November 2012). 